\title{
Bianca Bosker, Original Copies: Architectural Mimicry in Contemporary China
}

Hong Kong, Hong Kong University Press, University of Hawai'i Press, 2013, xii \& 164 pp.

\section{Martin Minost}

Translator. N. Jayaram

\section{(2) OpenEdition}

\section{Journals}

Electronic version

URL: http://journals.openedition.org/chinaperspectives/6337

DOI: 10.4000/chinaperspectives.6337

ISSN: 1996-4617

\section{Publisher}

Centre d'étude français sur la Chine contemporaine

\section{Printed version}

Date of publication: 1 December 2013

Number of pages: 83-84

ISSN: 2070-3449

\section{Electronic reference}

Martin Minost, « Bianca Bosker, Original Copies: Architectural Mimicry in Contemporary China », China Perspectives [Online], 2013/4 | 2013, Online since 01 December 2013, connection on 22 September 2020. URL : http://journals.openedition.org/chinaperspectives/6337 ; DOI : https://doi.org/10.4000/ chinaperspectives.6337

This text was automatically generated on 22 September 2020

(c) All rights reserved 


\section{Bianca Bosker, Original Copies: Architectural Mimicry in Contemporary China}

Hong Kong, Hong Kong University Press, University of Hawai'i Press, 2013, xii \& 164 pp.

\section{Martin Minost}

Translation : N. Jayaram

1 At the initiative of its mayor in 2001, Shanghai municipality launched an urbanisation programme entitled "One City, Nine Towns." The programme, integrated with an overall plan that included projects to develop some of Shanghai's satellite towns, planned the creation of ten new cities with experimental thematic zones featuring mainly European architecture. The result was construction of an "English neighbourhood" at Songjiang, a "German neighbourhood" at Anting, a "Dutch" one at Gaoqiao, a "Swedish" one at Luodian, and so on. The phenomenon of themed cities or areas in China featuring

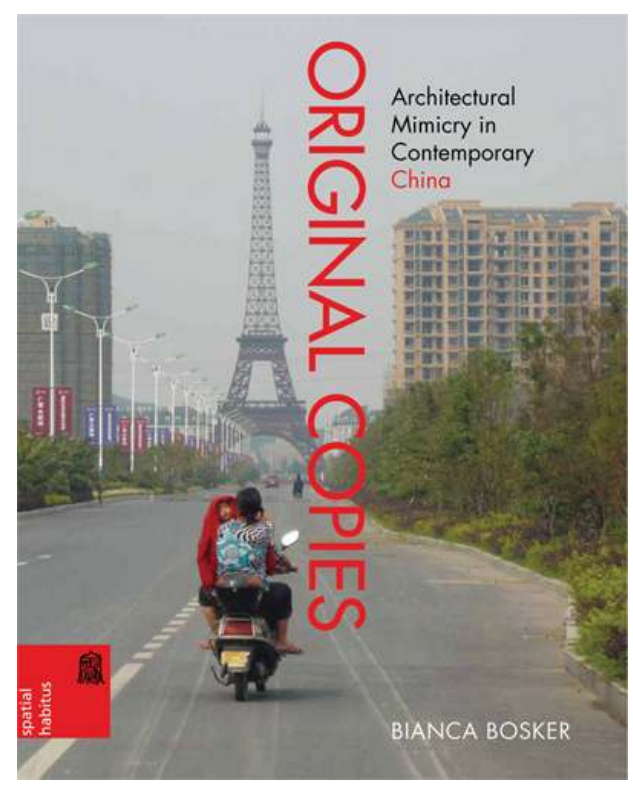
architecture inspired largely or even wholly by European and North American models has received little academic attention in the West thus far. However, many blogs collect news articles and accounts by foreign tourists and architects on this phenomenon, and the cities covered by the "One City, Nine Towns" programme have been in the spotlight especially in architectural circles. But these case studies 
constitute only the visible and well-reported tip of the iceberg and hide what in reality is a phenomenon that has spread throughout the country and that is much more intense as a result.

The book by Bianca Bosker, a graduate of Princeton University and now a journalist at Huffington Post, is a real tour de force in gathering a vast mass of documents and providing a description and general explanation of the phenomenon based on many cases.

3 She starts off by defining these objects, the "simulacrascapes" (perhaps the term alludes to Arjun Appadurai's ethnoscapes, but there is no reference to him in the book) as sociocultural products: the most recent manifestation of a culture of imitation that is properly Chinese as well as the result of social change in China through the rise of a wealthy middle class drawn to the image of success that European products evoke. With this definition, Bosker seeks to address through her analysis classic issues of imitated architecture since the phenomenon was born: how are Western features imitated? By what means? How is it seen and experienced? What motivated the construction of such structures? Who lives there? And why? What does it tell us about China today, at least in regards to the middle and upper classes and their quest for identity? The author also attempts to set out cultural reasons behind the emergence of the imitated cities phenomenon.

4 The second chapter sets out an argument seeking to prove that Chinese culture takes a different view of imitation, unlike the West, where only originality and authenticity would be valued. Numerous and diverse examples show that a good copy is valued in China, even and especially when difficult to distinguish from the original. Bosker notes this difference in values between China and the West to show the limits of post-modern analysis (comparing Chinese imitations with theme parks) to delve more deeply into the phenomenon's complexity and its particularity in China.

5 However, even if this theoretical analysis is needed to grasp the socio-cultural process at work, the China/West dichotomy as seen in the culture of copying versus authenticity is rather ambitious: examples based on particular links to imitation in China can be countered with counterparts from European history. While she has managed to skirt post-modern theory, which has generally been associated with new districts with foreign architecture, Bosker restricts herself to the vision of a bipolar world where two contrasting cultures oppose each other, China being seen as still subject to influences from a West reduced to a post-modern cosmology, although half a century old and still debated.

6 Such a reading seems to be one of the limitations in the author's analysis of the phenomenon. She tends to proceed from culturalist generalisations, whereas taking into account the social processes leading to the simulacrascapes would have helped her see the multiplicity of situations and take a more nuanced approach. An example of this problem crops up in the fourth chapter, in which Bosker seeks to understand the motivations behind the large-scale replication of foreign architectures and, simultaneously, reasons for not reproducing Chinese traditional architecture models. Her idea is that for the government, implicated at every level of decision-making, imitations of the West are a source of greater profit in the short term (as they convey an image of affluence and prestige) and symbolise China's capacity and power to close the gap and even overtake the West technically. In the author's eyes, copies of European traditional style constitute for the Chinese government a means of 
symbolically conquering the West's past and present, and the trophies of such conquest.

7 This explanation, generalised for all situations, must confront some reservations based on experiences on the ground. The fact is that Bosker's study, conducted between 2006 and 2008, was limited to imitations that were visible and accessible to the public, meaning that the state's implication was per force bigger given the touristic function and the symbolism of such zones. But there is a notable difference between copies such as those in the "One City, Nine Towns" programme - initiated by the mayor of Shanghai, the nation's economic capital, and thus naturally under media spotlight beyond China's borders - and zones closed to the public, such as the gated communities on Chongqing's periphery, for instance, whose architectural quality is appreciated by both institutions and residents - some neighbourhoods have been built by the private developer Longfor (Longhu) in Mediterranean styles - and where the local government's role was mainly to grant approval and cede land use rights. The motivations of the actors (government agents, promoters, buyers, and residents) vary according to context and situation, something Bosker sometimes forgets.

Nevertheless, the author's research provides a good deal of data on the forms such imitations can take, from simply copying to adhering more to a Chinese housing model (see Chapter Three). It is helped by rather impressive photographic documentation throughout the book, as well as information on local lifestyles. Although the research was focused on real estate promoters (apparently the author's main source of information, as well as architects and academics specialising in Chinese studies), Bosker also met residents who told her about their lives and aspirations (see the fifth and last chapter).

9 Therefore, apart from various interpretations of processes at work, be it from a more culturalist or socio-historic viewpoint, despite some drawbacks linked to an insufficiently circumscribed study matter and some disputable data, given that fieldwork is over five years old - which is considerable, given China's current rate of development - the book offers accurate and relevant information on the forms imitation takes, and changes in demand and in the capacities of China's new and upper middle classes and their situation. Above all, from a more general outlook, it shows that the style of replication of European architectures is an authentically endogenous phenomenon, in the sense that far from incarnating a process of externally forced acculturation linked to China's reintegration into globalised networks - a sort of "Americanisation" or "Europeanisation" - it reflects, on the contrary, a new form of what Thierry Sanjuan calls the "Chinese globalisation." 


\section{AUTHORS}

\section{MARTIN MINOST}

Martin Minost is contractual doctoral candidate in social anthropology and ethnology at the School for Advanced Studies in Social Sciences (EHESS, Paris), attached to the Research Centre on Modern and Contemporary China (CECMC - UMR 8173) (martin.minost@gmail.com). 